\title{
Indicators of labour standards: an overview and comparison
}

\author{
Working Paper No. 54
}

\author{
Richard N. Block*
}

Policy Integration Department Statistical Development and Analysis Unit International Labour Office Geneva

January 2005

*School of Labor and Industrial Relations, Michigan State University 
Copyright (C) International Labour Organization 2005

Publications of the International Labour Office enjoy copyright under Protocol 2 of the Universal Copyright Convention. Nevertheless, short excerpts from them may be reproduced without authorization, on condition that the source is indicated. For rights of reproduction or translation, application should be made to the Publications Bureau (Rights and Permissions), International Labour Office, CH-1211 Geneva 22, Switzerland. The International Labour Office welcomes such applications.

Libraries, institutions and other users registered in the United Kingdom with the Copyright Licensing Agency, 90 Tottenham Court Road, London W1T 4LP [Fax: (+44) (0)20 7631 5500; email: cla@cla.co.uk], in the United States with the Copyright Clearance Center, 222 Rosewood Drive, Danvers, MA 01923 [Fax: (+1) (978) 750 4470; email: info@copyright.com] or in other countries with associated Reproduction Rights Organizations, may make photocopies in accordance with the licences issued to them for this purpose.

ISBN 92-2-116989-8 (printed version)

ISBN 92-2-116990-1 (web version)

First published 2005

Cover:

The designations employed in ILO publications, which are in conformity with United Nations practice, and the presentation of material therein do not imply the expression of any opinion whatsoever on the part of the International Labour Office concerning the legal status of any country, area or territory or of its authorities, or concerning the delimitation of its frontiers.

The responsibility for opinions expressed in signed articles, studies and other contributions rests solely with their authors, and publication does not constitute an endorsement by the International Labour Office of the opinions expressed in them.

Reference to names of firms and commercial products and processes does not imply their endorsement by the International Labour Office, and any failure to mention a particular firm, commercial product or process is not a sign of disapproval.

ILO publications can be obtained through major booksellers or ILO local offices in many countries, or direct from ILO Publications, International Labour Office, CH-1211 Geneva 22, Switzerland. Catalogues or lists of new publications are available free of charge from the above address, or by email: pubvente@ilo.org

Visit our website: www.ilo.org/publns 


\section{Indicators of labour standards: an overview and comparison}

\section{Contents}

Preface

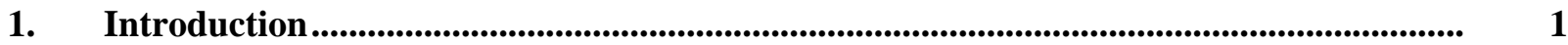

2. Measuring labour standards: Basic principles and methodology of Block-Roberts system

Basic Principles and Concepts

Governmentally-Created and Enforced....

Primary Effect on Workplace Transactions

3

Comparability in Purpose and Administration...................................................................... 4

Adoption or Possibility of Adoption in Both Countries.............................................................. 4

Scoring Methodology .........................................................................................................

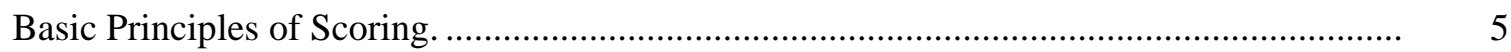

Creation of Numerical Index........................................................................................

3. Jurisdiction - specific issues: Comparing the United States and Canada ........................... 6

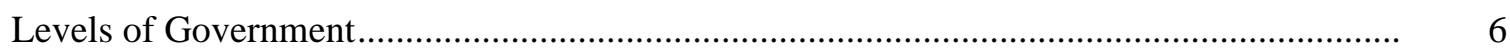

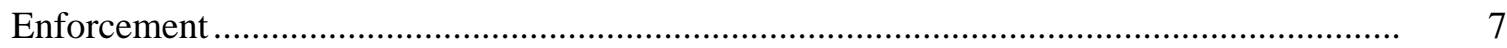

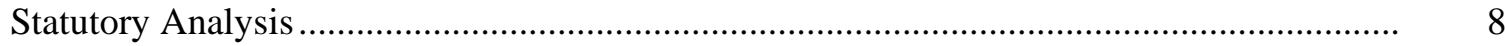

4. Labour standards in the United States and the European Union..................................... 9

5. Other methods for measuring labour standards.............................................................. 11

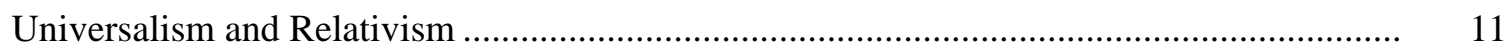

Measures of Labour Standards Used................................................................................... 12

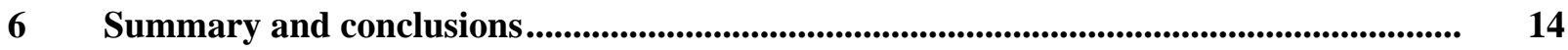

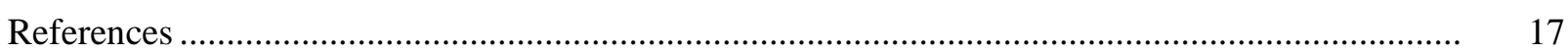

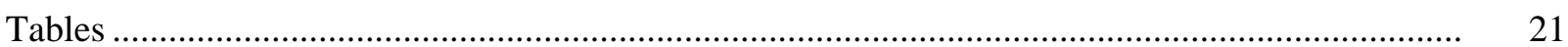




\title{
Preface
}

In September of 2004, the Policy Integration Department organized a technical staff seminar bringing together leading experts within and outside the ILO on so-called "qualitative" indicators of international labour standards. Recent years have seen a rapidly growing interest in the construction and use of such qualitative indicators among both researchers and policy-makers. This growth is arguably attributable to several factors, such as debates on the economics of labour standards, growing interest in socially responsible investing, and the recognition that statistics that are commonly used as quantitative indicators of labour standards are of limited value in capturing many aspects of labour standards and their application. Qualitative indicators of labour standards and worker rights, while numerical, address things that are intrinsically more qualitative in nature and are based, for example, on methods such as grading by experts and the coding of legislation and other textual sources. The rapidly growing interest in such qualitative indicators raises a number of questions about comparative methods for the construction of these indicators as well as the appropriateness of particular methods for particular uses, and these questions were the focus of the seminar.

"Indicators of Labour Standards: An Overview and Comparison" was presented at the seminar by Richard Block (Michigan State University). In this paper, Block presents the method he and Karen Roberts developed to address both legal and labour market outcome aspects of a wide range of labour standards regarding: minimum wages, overtime and working time, paid time-off, unemployment and employment insurance, workers' compensation, collective bargaining, equal employment opportunity, unjust discharge, occupational health and safety, advance notice, workers' rights to information and consultation, parental and family leave, and transfer of undertaking and ownership. The paper presents indicators constructed for the United States, Canada and the European Union and addresses the applicability of the method for developing countries. The paper also provides a comparison with other methods of quantifying labour standards, providing an assessment of their different strengths and weaknesses.

As a working paper, this represents the views of the author and is intended to stimulate debate. It is published as a contribution to work in the ILO on developing the statistical analysis dimension of decent work.

\author{
Peter Peek \\ Manager \\ Statistical Development and Analysis Unit \\ Policy Integration Department
}

January, 2005 


\section{Introduction}

Questions of labour standards and their impact on trade continue to be an important area of debate (Flanagan and Gould, 2003; Elliott, 2004; Becker, 2004). The fundamental question continues to be whether, other things equal, in a globalized economy moving toward free trade, differences in labour standards among trading nations give lower labour standards countries an (unfair) advantage in trade by providing a cost advantage to producers in those lower standards countries. The assumption in much of this literature seems to be that labour standards did matter; that a country could obtain trading benefits from relatively low labour standards (Block, Roberts, Ozeki, Roomkin, 2001).

For many years, much of the debate around the relationship between trade and labour standards was based on economic theory and arguments based on social equity, often questioning whether any such "advantage" given to low labour standards countries is "unfair" (Block, Roberts, Roomkin, and Ozeki, 2001). But there had been little empirical work to determine whether labour standards had an effect on trade and related economic phenomena, such as investment, and, if so, how much of an effect. The absence of empirical work was due, in large part, to the absence of measures of differences in labour standards among countries.

Thus, the first step in the process of determining the impact of differential labour standards across countries has been to measure differences in labour standards across counties. This paper will discuss the methodology Karen Roberts and I have developed to attempt to fill this measurement gap. Part II of the paper will discuss the basic principles of the BlockRoberts system, including definitions and scoring methodology and assumptions. Much of this will cite our Upjohn book. As an illustration of the basic principles of the system, Part III of the paper will focus on the application of the system in a comparison we did of the United States and Canada, again citing our Upjohn book. Part IV will examine our work comparing the U.S. and the E.U., including how the basic methodology was modified to adapt it to the U.S.-E.U. comparison. This section will also briefly summarize the U.S.E.U. results, published elsewhere (Block, Berg, and Roberts, 2003). Part V will compare the methodology with the methodology used by others who have quantified labour standards, focusing on strengths and weaknesses of the various approaches. Part VI will provide a summary and conclusion. 


\title{
2. Measuring labour standards: Basic principles and methodology of Block- Roberts system
}

\section{Basic Principles and Concepts}

The initial step in the process of quantifying labour standards on an international basis, or more generally, across political jurisdictions, ${ }^{1}$ is to establish a definition of labour standards that will be valid across the jurisdictions. If one defines a "labour standard" as a minimum working condition to which all employers in the affected jurisdiction must adhere, it is clear that there are varying methods of creating labour standards. For example, many European countries use agreements established via corporatist institutions to establish employment standards that apply to all firms and employees within the scope of the institution (Turner, 2002). Similarly, in South Korea prior to the IMF intervention of 1995, an informal, standard for lifetime employment in the chaebols, the large conglomerates, had developed through an implied agreement among the government, unions, workers, and the employing chaebols (Lee, 1997; Block, Lee, and Shin, 2002). Private organizations, such as Social Accountability International, promulgate labour standards that they hope firms will adopt through market pressure and publicity (Social Accountability International, undated).

While all of these systems create minimum standards for workers, they do not constitute labour standards if that term is used as applying to a standard that affects all workers within the jurisdiction rather than to subgroups of workers. Taking this into account, In order to be considered labour standards for our purposes the standards must be: (1) governmentally created and enforced; (2) designed to affect or regulate workplace transactions for all or almost all employees in the political jurisdictions studied, with any exclusions legislative; (3) generally comparable in purpose and administration across jurisdictions studied such that a fair comparison can be made; and, (4) have been adopted or could reasonably be adopted in all the of the jurisdictions analyzed. Thus, we used the following definition of a labour standard:

\begin{abstract}
"a labor standard is any governmentally established procedure, term or condition of employment or employer requirement that has as its purpose the protection of employees from treatment at the workplace that society considers unfair or unjust. The common element across all standards is that they are mandatory - they are governmentally imposed and enforced. Employer failure to comply with the standards brings legal sanctions upon the employer. This provides the universal or potentially universal coverage that is needed. There may be statutory exclusions, but these can be accounted for and estimated” (Block, Roberts, and Clarke, 2003).
\end{abstract}

This definition incorporates each of the four components. The rationale for each of the components will be discussed.

1 The term political jurisdiction is used in order to recognize that the national government at the country level is not the only governmental entity that establishes labor standards. In Canada, the provinces, sub-national jurisdictions, have the primary responsibility for establishing labor standards (Block and Roberts, 2000; Block Roberts, and Clarke, 2003). In the United States, the establishment of labor standards is shared between the national government and the individual states (Block, Roberts, and Clarke, 2003). In Europe, standard setting authority is shared between the super-national European Union and the E.U. member states (Springer, 1994; Block, Berg, and Roberts, 2003) 


\section{Governmentally-Created and Enforced}

The requirement that the standards included in our analysis be governmentally created and enforced ensures that they are or could, if the legislating body so chose, be applied to all employers and employees in the political jurisdiction. Although, as will be discussed below, there may be statutory exemptions, these exemptions are created by choice of the legislating body and could, in principle, be addressed through the value attributed to the standard. Through legislation, government can be seen as establishing a minimum, legally enforceable floor for labour standards (Block, Roberts, and Clarke, 2003).

It is acknowledged that there are other sources of benchmarks for practices, such as custom and practice in the locality or industry, the market, and collective bargaining. Thus, in the U.S., custom and practice may determine that employees receive paid days off for holidays, but such paid days are not mandatory. Similarly, collective bargaining may define standards, but the standards are only applicable to the employers and employees covered by the bargain. In addition, exceptions can be negotiated. ${ }^{2}$

Examples of this criterion operating in practice are our consideration of vacations (paid annual leave) in the U.S.-Canada analysis and our exclusion of health care from the U.S. Canada analysis (Block, Roberts, and Clarke, 2003). We consider the United States as not providing vacations because there is no legal requirement on the Federal level or in any state that employees receive vacations, although there is a custom and practice that employees receive vacation pay. ${ }^{3}$ Similarly, we exclude health care because there is no legal requirement in the U.S. that employers provide employees with health insurance, although there are equal employment opportunity requirements on employers that choose or are required by collective bargaining agreements to provide their employee with health insurance. In Canada, health care is provided to all citizens outside of the employment relationship.

\section{Primary Effect on Workplace Transactions}

The second major criterion for inclusion in the study as a standard was that the law or regulation was designed to have its primary application at the workplace or its primary effect on workplace transactions in both countries. Matters that may have some linkage to the workplace or work relationship, but do not have the workplace as their primary focus, were excluded.

2 For example, in the construction industry in the US, unions and contractor often negotiate project-specific agreements in order to permit unionized contractors to compete with nonunion contractors (Dunlop, 2002).

3 For example, The United States Bureau of Labor Statistics estimates that, in 2003, 79\% of all workers in private industry in the U.S. received some paid vacation (annual leave). 
An example of using this criterion as the basis for excluding a provision from consideration as a labour standard in the U.S.-Canada analysis is the treatment given to Social Security in the United States and the comparable programs in Canada. Although these programs are (at least partially) financed through the employment relationship, their primary purpose is to act as an insurance program for persons who are out of the labour force, either because of retirement or because of a permanent disability. They are not primarily designed to influence workplace transactions. ${ }^{4}$ (Block, Roberts, and Clarke, 2003).

\section{Comparability in Purpose and Administration}

This criterion captures the principle that it is important to limit the analysis to those standards that can be fairly compared. This principle was used was a second reason why we excluded from the analysis the public pension systems in the two countries, social security and related programs in the United States and Old Age Security and the Canada Pension Plan and related programs in Canada. The system in the United Sates is fully funded by workplace-based (employer, employee, and self-employed person) payments and interest, while the system in Canada is funded by a combination of workplace-based payments, interest, and general tax revenues (HRDC, 1998a; HRDC, 1998b). In our judgment, this difference made these two programs noncomparable.

\section{Adoption or Possibility of Adoption in Both Countries}

The fourth major criterion for including a law or regulation as labour standard in the analysis is that the law or standard could reasonably be adopted in both countries. For example, because the purpose of the U.S.-Canada analysis was ultimately to develop a scoring for and ranking of labour standards in the 63 jurisdictions of the United States and Canada, it would have been misleading to "score" a jurisdiction and/or a country lower than it would otherwise be scored because it does not have standard or a provision that one would not think it could reasonably adopt. For example, again using health care, one would not reasonably expect any Canadian jurisdiction to adopt a labour standard requiring health insurance be provided to all employees because the state provides health care to all of its citizens through the general tax system of federal and provincial personal and corporate taxes (Health Canada, 1998). In other words, health care is not a workplace issue in Canada as it is in the United State. While employers in the Untied States could, in principle, be required to provide health care, it would be inappropriate to consider it as labour standard in a U.S - Canada comparison because it is not a labour standard in Canada.

4 Of course, to the extent that employers pay social security taxes, such taxes increase the cost of hiring employees and may create disincentives to hire workers. But such taxes to not directly regulate the workplace. 


\section{Scoring Methodology}

\section{Basic Principles of Scoring}

We conceived of labour standards as incorporating (1) the substance of the standard as determined by the enabling legislation and (2) the rigor with which the legislation is enforced. The methodology for comparing the labour standards and for computing a "basic labour standards index" involves three components: (a) an analysis of the substance, that is, the statutory or legislative provisions of each of the standards; (b) development of an index of the strength of the labour standard in a jurisdiction based on the substance of the legislation; and (c) a method of measuring the rigor with which the standards are enforced. ${ }^{5}$ (Block, Roberts, and Clarke, 2003).

\section{Creation of Numerical Index}

Once the components were determined from the legislation, an index was created for each of the standards. The index for each standard consists of a sub-index for the provision that is greater the greater the level of protection given to employees; and a weight given to each provision within each standard. Enforcement mechanisms were treated as additional provisions and were assigned a weight. (Block, Roberts, and Clarke, 2003).

For each provision, an ordinal scale was constructed. Values were assigned to each relevant statutory provision or enforcement mechanism by assigning to the absence of a provision, a score of zero $(0)$ and the strongest provision among all the jurisdictions a score of ten (10). Provisions of intermediate strength were assigned intermediate values in accordance with the number of possible categories in the provision. (Block, Roberts, and Clarke, 2003)

Generally,

let $\mathrm{s}_{\mathrm{pdj}}=$ the score assigned to provision $\mathrm{p}$ in standard $\mathrm{d}$ in jurisdiction $\mathrm{j}$, where 0 \# $\mathrm{s}_{\mathrm{pdj}} \# 10$ and where 10 is the score assigned to the most favorable standard among all $\mathrm{j}$ jurisdictions analyzed;

let $\mathrm{w}_{\mathrm{pdj}}=$ the weight assigned to provision $\mathrm{p}$ in standard $\mathrm{d}$ in jurisdiction $\mathrm{j}$, where $0 \# \mathrm{w}_{\mathrm{pdj}} \#$ 1 ;

5 We also created a "coverage deflated index" which deflated the basic index by an exclusions from coverage. In the United States, it is not unusual for a labor standard to exclude specific industries, occupations, employers, or types of employees. For example, the National Labor Relations Act, the statute that governs labor-management relations in the United States, and protects employees in their rights to unionize, excludes employees who are supervisors, as defined in the law. For a detailed discussion, see United States General Accounting Office, 2002. 
Then, the basic index score for standard $d$ for jurisdiction $\mathrm{j}$ is:

$\mathrm{X}_{\mathrm{dj}}=\mathrm{E}^{\mathrm{n}} \mathrm{S}_{\mathrm{pdj}} * \mathrm{~W}_{\mathrm{pdj}}$ where the index consists of $\mathrm{n}$ provisions.

The standard scores can be summed to provide an overall labour standards score for a jurisdiction. The labour standards index for jurisdiction $j$ is denoted as $L_{j}$. Then,

$$
\mathrm{L}_{\mathrm{j}}=\mathrm{E}_{j}^{\mathrm{n}} \mathrm{X}_{\mathrm{dj}} . \quad \text { (Block, Roberts, and Clarke, 2003). }
$$

For example, for collective bargaining laws, jurisdictions in which union recognition could be obtained without an election were assigned a value of 10, and jurisdictions in which an election was required were assigned a value of 0 . Thus, for this labour standard provision, there were no intermediate values. In contrast, advance notice requirements for large-scale layoffs provide an example of a provision that requires an intermediate coding. If the provision of the statute in the jurisdiction required advance notice of greater than or equal to 16 weeks, the jurisdiction was coded as a 10 . Notice of 12 to 16 weeks was coded as 7.5, 8 to 12 weeks notice as coded as 5.0, 4 to 8 weeks as 2.5, and no provision was coded as zero. (Block, Roberts, and Clarke, 2003)

As indicated above, the jurisdiction which provides the highest level of protection to employees is scored as a 10. Thus, the system is relativistic rather than absolutist. The highest possible score is not based on an absolute standard of protection, but on a standard of protection that is actually provided to employees.

In addition to coding each provision, a weighting scheme was established for provisions within a labour standard, reflecting our assessment of the importance of the provision to the standard. The limitation we used that that the weights of the provisions within a standard must total to $1 .^{6}$ (Block, Roberts, and Clarke, 2003).

\section{Jurisdiction - specific issues: Comparing the United States and Canada}

\section{Levels of Government}

Although the scoring principles are uniform, as they are based on the legislated characteristics of labour standards, when adapting the methodology to compare two or more political jurisdictions, one must also take into account the specific characteristics of the standard setting process in those jurisdictions. When analyzing the United States and Canada, this meant taking into consideration the fact that different levels of government

6 Realizing that the indices are a function of the weights given to each relevant provision, and also realizing that weights are based on judgments about which reasonable people may differ, we computed indices with three different sets of assumptions about weights. See, Block, Roberts, and Clarke, 2003. 
promulgate standards in the two countries. In the United States, most labour standards are promulgated at the national level, but some important ones are adopted by the individual states. Moreover, in the United States, states have the option, for some standards, of adopting a standard that is higher than the federal standard. Canada, on the hand, has no national labour standards that apply to all workers in the country.

For most workers in Canada, labour standards are adopted at the provincial level, covering all workers in the province. The exception is industries that are primarily inter-provincial (Block, Roberts, and Clarke, 2003). ${ }^{7}$ Put differently, within the U.S. and Canada, there were 63 jurisdictions that promulgated, or could promulgate, labour standards - the U.S. federal government, 50 states, ${ }^{8} 10$ provinces, two territories, ${ }^{9}$ and the Canadian federal jurisdiction. Thus, in analyzing the U.S. and Canada, it was necessary to measure labour standards at both the national and sub-national levels.

\section{Enforcement}

Second, in examining the U.S. and Canada, we also considered jurisdiction-specific issues in measuring enforcement. Although an ideal measure would have been enforcement aggressiveness as measured by the budget per covered employee budget of the enforcing agency, we learned that the agencies in the two countries and the 63 states, provinces, and territories were dissimilar in mission; some had missions beyond labour standards, such as housing, and others did not. Therefore, our measure of enforcement was the right of the losing party in a case to appeal to the judicial system outside the agency dedicated to enforcing labour standards. Our view was that the broader the rights of appeal from the decision of the administrative agency charged with enforcing the labour standards legislation, the weaker the enforcement. In addition to the rationale of "justice delayed, justice denied," the use of appeal rights was also based on the notion that a government agency charged with administering a standard will be expert in administering that standard and will be likely to interpret that standard in a way that is sensitive to the employee beneficiaries of the statute. A court, on the other hand, that enforces all laws, is likely to see its role as interpretation of a statute in the context of other, nonstatutory considerations that may not be consistent with the employee orientation statute and the specialized agency (Crowley, 1987; Brudney, 1996, Block, 1997, Block, Roberts, and Clarke, 2003). Therefore, a broad scope for appeal and judicial review of labour standards agency decisions is likely to result in interpretations of the statute and standards that are relatively unfavorable to employees. Therefore, for the U.S-Canada study, the enforcement standard was based on the right of appeal. (Block, Roberts, and Clarke, 2003).

7 The labor standards in the following sectors are federally regulated in Canada: air transportation, banking, broadcasting, communications, crown corporations (such as Canada Post), flour, feed mills, grain elevators, longshoring, interprovincial and international railways, interprovincial and international road transport, shipping and navigation, and various miscellaneous industries. See Canada Labour Relations Board, 1991; Block, 1997.

8 For simplicity, we excluded from our analysis the District of Columbia and U.S. territories, such as the U.S. Virgin Islands and Puerto Rico.

9 Since the study was done, a third territory, Nunavut, was established from the western portion of the Northwest Territories. 


\section{Statutory Analysis}

Columns II and III in Tables 1-10 contain the components and coding of the indices used to compare the United States and Canada (Block, Roberts, and Clarke, 2003). In order to minimize the number of tables, and to facilitate a comparison between the U.S.-Canada analysis and the U.S.-E.U. analysis in the next section, the presentation is made with dualpurpose tables. For those standards for which we conducted both a U.S.-Canada and U.S.-E.U. analysis, the tables display the provisions and the coding for both analysis. For those standards for which only one analysis was done, only the coding for that analysis is presented in the tables. Tables 1-3, 6-7, and 9-10 present data for the both the U.S. Canada and the U.S. - E.U. analyses. For these seven tables, the relevant columns for the U.S.-Canada analysis are I, II, and III. Tables 4, 5, and 8 contain coding only for the U.S. and Canada. The overall comparison for the U.S. and Canada is presented in Appendix 1.

As can be seen, and as outlined above, each of the standards is divided into provisions, and each of the provisions is assigned a weight such that the total of the provision weights equals 1 . Within each of the provisions, a greater weight is assigned to provisions that offer greater protection to workers, with the highest level of protection among all the jurisdictions assigned a value of 10 .

Turning to Table 1, within the minimum wage standard, by far the greatest weight was attributed to the level of the minimum wage, with lesser weights from some ancillary provisions. For the overtime/working time standard, the components of which are shown in Table 2, the greatest weight was given to the existence of overtime legislation. The paidtime off index time, presented in Table 3, was based on a detailed coding of the state and provincial statutes. As paid time-off was regulated at the state and provincial levels, it was important to analyze these details.

Tables 4 and 5 present the components for the employment/unemployment insurance and workers' compensation indices. As these are also regulated at the state and provincial level in the United States in Canada, they were analyzed in detail.

Table 6 presents the components of the collective bargaining index for the U.S. and Canada. Although the U.S. regulates collective bargaining at the national level, while Canada regulates collective bargaining at the provincial level, both countries are characterized by majoritarian systems based on majority rule with administration by a specialized agency. Therefore, the analysis was based on components of the law within a majoritarian system that were thought to strengthen or weaken the rights of employees to unionize.

Table 7 presents the components of the anti-discrimination index. It takes into account protection of the expected classes of employees. Table 8 presents the components of the unjust discharge index. It is based on state level legal developments in the U.S. regarding exceptions to the prevailing employment-at-will doctrine as compared with the Canadian legal principles, which generally limit discharge except for just cause.

Table 9 presents the components of the occupational safety and health (OSH) index. It is based on the North American system of standard setting with inspections. It also incorporates the principle of penalties. As shown in Table 10, advance notice provisions are similarly structured in both countries, with notice requirements and notification requirements. 


\section{Labour standards in the United States and the European Union}

In analyzing the United States and the E.U., as with the U.S.-Canada analysis, we first considered governance differences between the E.U. and the U.S. ${ }^{10}$ We analyzed only standards that were regulated at the national level in the U.S. and the community level in the E.U., standards that were regulated at the national level in the U.S. but were not addressed at the community level in the E.U., and standards that were regulated at the community level in the E.U. but not regulated at all in the U.S. If a standard was addressed at the community level in the E.U. but not at the federal level in the U.S., it was presumed that the U.S. made a choice not to regulate. Similarly, if a standard was regulated at the federal level in the E.U. but not at the community level in the U.S., it was presumed that the E.U. made a choice not to regulate. In essence, the country in the U.S and the community in the E.U. were treated as comparable levels of analysis. We did not consider standards that existed in both jurisdictions but were not regulated at the comparable levels. Therefore, standards that were regulated at state level in the U.S or the country level in the E.U. were excluded because they were presumed to be regulated at different levels. (Block, Berg, and Roberts, 2003).

Based on this, ten standards were analyzed. Seven, minimum wage, overtime/working time ("overtime" in the U.S. - Canada study), paid-time off, collective bargaining, antidiscrimination, occupational safety and health, and large-scale layoffs, were included based on their inclusion in the U.S. - Canada analysis, because the U.S regulated these standards at the federal level, and because they were regulated at the community level in the E.U.. The components and weighting of these indices for the U.S.-E.U. analysis are shown in Columns IV and V of Tables 1-3, 6-7, and 9-10. Three standards that were included in the U.S. - Canada analysis - unemployment/ employment insurance, and unjust discharge - were excluded because they were regulated at the state level in the U.S. - workers' compensation, unemployment insurance, and unjust discharge.

Three additional standards were included because they were regulated at the community level in the E.U. but not at that state level in the U.S. These standards were information and consultation, parental leave, and transfer of undertaking ownership. The components and weightings for these standards are presented in Tables 11-13.

In comparison with the U.S.-Canada study, the internal benchmarking principle also required that the provisions within some standards be changed to accommodate matters within the standard that are regulated in the E.U. but not in the U.S. or Canada. This resulted in changes in the overtime index, which was changed to overtime/working time and the collective bargaining indices, to which was added a provision on union involvement in policymaking. The overall comparison between the U.S. and the E.U. is presented in Appendix 2.

Because the U.S. regulates the minimum wage at the national level, and the E.U. does not, and there is no regulation at the country level in the E.U., they were compared based on the U.S. standard. The U.S. index was 9.5, while the E.U. index was zero (Block, Berg, and Roberts, 2003).

10 An analysis of labor standards in the United States and the European Union presumes that it is appropriate to compare the United States, a sovereign nation, with the E.U., a political and economic union of sovereign nations. For the rationale for comparing the U.S. and the E.U., see Block, Berg, and Roberts (2003). For a comparison of governance assumptions in the E.U., the U.S, and Canada, see Marleau, 2003. 
As shown in Table 2, the overtime/working time index was changed substantially for the U.S.-E.U. analysis. As the U.S. and the Canadian provinces regulate working time only through overtime, that was all that was necessary for the U.S.-Canada analysis. But, under the principle of benchmarking at the highest standards in the jurisdictions studied, the extensive regulation of working time in the E.U. required the addition of several provisions adopted by the E.U. that have not been adopted by the U.S. Therefore, regulation of meal periods, rest periods, maximum hours, mental or physical stress was added to the working time index. The overtime provision was reweighted from .95 in the U.S.-Canada analysis to .35 in the U.S.-E.U. analysis because of these additional provisions. Because of these additional provisions, the E.U. index was 5.5 and the U.S. overtime/working time index was 3.5 (Block, Berg, and Roberts, 2003).

Unlike the U.S.-Canada analysis, which focused on the lower levels of government and could accommodate detailed differences among the states and provinces, the E.U.-U.S. analysis was done at the highest governmental level. Thus, broader indicators of the provisions, in this case the existence of certain standards, were analyzed, but detail was excluded, as shown in Table 3 for the paid time-off index. The E.U. paid-time off index was 7.5, while the U.S. paid time-off standard was .83 (Block, Berg, and Roberts, 2003).

The collective bargaining index underwent a similar change, as shown in Table 6. The U.S. chooses to provide detailed rights at the national level, while the E.U. limits its community-level regulation of collective bargaining to the somewhat legally ambiguous Charter of Fundamental Rights. On the other hand, the index was expanded from the narrow legislative focus of the U.S. to include formal participation in policy-making. Nevertheless, the result, based on the level of analysis, was an index that resulted in higher score for the U.S. than the E.U., 6.67 as compared to 3.3 involving a change in the scope and direction of the enterprise.

As can be seen in Table 7, the structure of the anti-discrimination index in the U.S.-E.U. study was similar to the structure of the index in the U.S.-Canada comparison. Discrimination based on political beliefs was excluded because neither jurisdiction addressed it, as was enforcement. This required a slight reweighting of the components. Nevertheless, both jurisdictions have almost identical scores, 10 for the E.U., 9.35 for the U.S., with the difference due to the fact that the U.S. does not prohibit discrimination based on sexual orientation. (Block, Berg, and Roberts, 2003).

Table 9 demonstrates the revision of the occupational safety and health (OSH) index for the U.S.-E.U. analysis. Rather than focusing on details of standards, as was necessary for the U.S.-Canada comparison, the analysis incorporated broader provisions. Provisions on worker consultation, worker information, worker training, and the working environment were also added to the index because of E.U. directives. This resulted in substantial reweighting. The E.U. score on occupational safety and health was 8.0, while the U.S. score was 3.5. (Block, Berg, and Roberts, 2003).

As can be seen in Table 10, advance notice principles are basically the same in the U.S. and the E.U.. The greatest weight in both countries was given to exclusions, on the grounds that such exclusions reduce the reach of even the broadest set of protections. The E.U. score on advance notice was 8.75, while the U.S. score was 8.25. (Block, Berg, and Roberts, 2003). 
Tables 11-13 were new standards developed for the U.S.-E.U. study. Table 11 on consultation, and Table 13 on transfer of ownership are standards that do not exist in the U.S. and Canada. In the U.S.-Canada study, family leave was included as part of the antidiscrimination index because its origins in both countries were associated with gender equity in employment. Given the importance of these leaves in the E.U., and their basis in social equity and broad-based notions of worker health, a separate index was used. This is shown in Table 12. For the information/consultation index, the E.U. was scored as a 10, the U.S. was scored as 0. For the parental and family leave index, both jurisdictions were scored a 5. For the transfer of ownership obligations, the E.U. scored 10 and the U.S. scored .75. (Block, Berg, and Roberts, 2003).

\section{Other methods for measuring labour standards}

The foregoing discussion highlighted two important characteristics of the Block-Roberts labour standards measure. First, it is relativistic rather than universalistic. The benchmark is not an external standard, but rather the highest standard within the jurisdictions compared. Second, the definition of labour standards used is narrow. It is limited to legislation designed to benefit workers by directly influencing the allocation, hiring, or price of labour.

This section will compare our measures with measures of labour standards used in other studies. As will be discussed, those other measures have components that are universalistic or use a broad definition of labour standards. The advantages and disadvantages of our measure and these other measures will be discussed.

\section{Universalism and Relativism}

Measures of the levels of labour standards across countries have generally relied on ILO Conventions as a benchmark. Rodrik (1996) uses the number of ILO Conventions and the number of "basic" ILO Conventions ratified. The OECD (1996) also uses ILO Conventions ratified. Mai (1997) used a dummy variable for each of the core labour standards analyzed to examine the impact of differences in labour standards on exports in 45 developing countries. Busse (2001) uses the number of "core” ILO Conventions ratified. Ratification, or non-ratification of core (fundamental) ILO Conventions ratified is the largest component of Böhning's (2003) indicator of the worker rights gap in a country, although he also measures adherence through the ILO's internal complaint procedure. Maskus' (2003) measure of labour standards includes the number of fundamental ILO Conventions ratified. Flanagan (2003) uses the number of core and noncore labour ILO Conventions ratified. All of these studies examined the impact of labour standards in a wide range of countries.

The advantage of using ratification of and/or compliance with ILO Conventions, in some form, is that the Conventions are internationally recognized as benchmarks. Moreover, ratification and compliance are identifiable, voluntary actions by a country that indicate that the country is willing to provide protection to workers. Moreover, given the breadth of countries studied in these studies, a board-based measure was necessary.

There is however a key disadvantage to using data on ILO Conventions as a measure of labour standards across countries. This disadvantage revolves around the question of the universality of the standards. There may be a great range of statutory protections that would be consistent with a ratified Convention (Block, Roberts, Ozeki, and Roomkin, 2001). Moreover, as Böhning (2003) notes, not all countries have similar capacities to implement or enforce ratified Conventions. Thus, there is likely to be substantial 
measurement error in any variable that considers labour standards to be roughly equivalent in two or more countries that have ratified the same Conventions. Indeed, as Rodrick (1996) points out, Conventions ratified, per se, may not be a valid measure of labour standards. Many less developed countries have ratified more ILO Conventions than the U.S. Yet, even with its low level of labour standards relative to Canada and the E.U. other developed countries (Block, Roberts and Clarke, 2003; Block, Berg, and Roberts, 2003), it is not reasonable to believe that that the U.S. has lower standards than many less developed countries that have ratified more ILO Conventions.

The fact that the lack of universality could be associated with measurement error is consistent with Flanagan's (2003) somewhat unexpected findings of no evidence of a relationship between ILO Conventions ratified and actual labour conditions, operationalized as child labour, civil liberties, and life expectancy. The finding of the absence of a relationship could be due to measurement errors in labour standards measures that rely heavily on ILO ratifications.

\section{Measures of Labour Standards Used}

As noted, a second difference between the Block-Roberts measure of labour standards and the measures used in other research is definitional. What is meant by a "labour standard?" Some researchers use a measure based on law and legislation. Within this category of variables are "pure" measures of labour standards that are limited to laws that regulate the labour market, and broader measures that incorporate political and social rights. Other researchers use a blend of legislative and labour market outcome measures.

A "pure" measure of labour standards is used by Heckman and Pages-Serra (2000), who measure employment security in Latin American, Caribbean, and OECD countries using a measure based on the period of advance notification and money compensation for dismissal, the probability of remaining on the job, the maximum tenure that an employee can remain with the firm, the probability of economic difficulties will justify dismissal. Thus, the Heckman/Pages-Serra measure is based primarily on legislation.

Galli and Kucera (2004), in their examination the effect of labour standards on informal employment in Latin America use Kucera's measure of Freedom of Association and Collective Bargaining (FACB) rights. This measure is based on Kucera's (Kucera, 2001; Kucera and Sarna, 2004) method of evaluating de jure and de facto FACB rights in different countries by the ILO, the International Confederation of Free Trade Unions, and the U.S. Department of State, and the Heckman/Pages-Serra (2000) employment and job security indices. These are fairly pure labour legislation measures. In their correlation analysis, Galli and Kucera also used the Freedom House political and civil liberties index, which can be considered broader legislation, and a measure of unionization, which is an outcome measure.

Similar to the methodology of Galli and Kucera (2001), Cuyvers and Van Den Bulcke (2004), use an ILO Convention ratification data and other data on enforcement and government actions. The Convention data are used to create a "formal" freedom of association index, while the non-ILO data are added to create a "real" freedom of association index.

Researchers use a combination of legislation-related and outcome related variables. Rodrik's (1996) model includes both legislative-type measures of labour standards (Conventions ratified, basic - now fundamental - Conventions ratified, child labour standards, statutory hours, granting of leave), and labour market or institutional characteristics that may be related to labour standards but are not derived directly from labour standards legislation (unionization, measures of civil and political rights). Busse (2001) uses as a measure of core labour standards compliance (ratification) with ILO 
Conventions. But he also uses labour market measures. His measure of the core labour standard "the degree of discrimination against women in working life," is "the percentages of male and female population ages 15-64 that are working” (Busse, 2001, p. 3). Another measure of a core labour standard, child labour, is defined as the percentage of the population aged 10-14 that is working. The forced labour standard is a measure of the prevalence of forced labour.

Maskus (2003), analyzing the labour standards in primarily developing countries, uses as a measure of labour standards a blend of political rights through the Freedom House index, per capita income as a measure of wealth, labour standards based on fundamental ILO Conventions ratified, a capacity to enforce laws, and an assessment of level of compliance with core labour standards. Kucera and Sarna (2004) limit their analysis to the relationship between trade and rights of freedom of association/collective bargaining. But they too estimate a blended model, using the Kucera measure of FACB rights, the Freedom House indices, and unionization. ${ }^{11}$

A middle ground between outcome data and legislation is used by Cuyvers and Van Den Bulcke (2004) to create a "real" child labour index to pair with their "formal" child labour index. Their "real" index incorporates ILO Convention data and data on economically active children 10-14 years of age. On the one hand, the latter can be classified as outcome data, because it is not derived directly from the legal system. On the other hand, it is not likely that the labour force participation of children 10-14 would be high without a lack of enforcement.

The advantage of broadening the measure of labour standards used is that the task of analyzing the effect of labour standards over wide range of countries and development is eased. Narrower measures, which are based on precise definitions of legislation, reduce the number of countries that can be studied. The more countries one includes in the model, the greater the variation in legislation for which one needs to account.

A disadvantage of broadening the measures of labour standards is that one is not necessarily measuring true labour standards or labour market regulation. Measures such as unionization and female labour participation are not truly measures of labour standards. These measure labour market characteristics which are presumed to be associated with, and more importantly, affected by or affect labour standards. With respect to labour market characteristics, these variables assume what they hope to show, that labour standards matter. It is assumed, for example, by Maskus (2003), that low labour force participation by women is due to low anti-discrimination standards. But it might also be the case that other factors besides low levels of anti-discrimination laws affect female labour force participation.

11 Interestingly, Kucera and Sarna (2004) do not use Convention ratification per se as an independent variable. 
With respect to the political environment variables, it is presumed that greater democracy leads to improved labour standards. While this may true when analyzing labour standards across both developing and developed countries, it may be less true when the analysis is limited to only developed countries. The U.S. and Canada, for example, are both free, according to Freedom House (Freedom House, undated-b), but have different levels of labour standards (Block, Roberts, and Clarke, 2003). In addition, it is not always true that democracy means higher levels of labour standards, at least at a point in time and within a country. Democratically elected right-leaning governments may reduce labour standards, within limits. ${ }^{12}$

\section{Summary and conclusions}

This paper has examined the Block-Roberts methodology for measuring labour standards and has compared it with other research that has measured labour standards. The main characteristics of the Block-Roberts method are its relativism and the narrowness of its definition. It is relativistic in the sense that it does not rely on a universal benchmark, such as ILO Conventions. Rather it uses as a benchmark the most generous provision and standard in the jurisdictions being studied. The advantage of this method is that it is based on a benchmark that is politically feasible, because it has been enacted in at least one jurisdiction. The disadvantage of this method is that it is best for studying countries/political jurisdictions at comparable levels of development and with comparable levels of democracy.

The second major characteristic of the Block-Roberts method is the strictness of its definition. We define a labour standard as being governmentally adopted and enforced (and, therefore mandatory), workplace-oriented, comparable in purposes, and, in a sense adoptable by all the jurisdictions compared. The advantage of this definition is its purity; all of the standards included have similar characteristics. Moreover, if used as independent variable, the inferences to be drawn from any results are clear.

The disadvantage of strict definition is the narrowness of its application. The stricter the definition, the more difficult it is to bring countries at different developmental levels into the analysis. It does not consider such issues as retirement and social security, issues linked to the labour force, but necessarily to the workplace.

Another important issue that must be addressed involves differences within countries. The U.S. - Canada analysis addressed sub-national differences because sub-national political jurisdictions in these two countries promulgate labour standards. To the extent subnational political jurisdictions within a country adopt labour standards, ideally, the measure of labour standards should account for these differences.

12 The Conservative Thatcher government in the UK in the 1980's enacted legislation that restricted union action, although there is a debate about the extent to which the fundamental collective bargaining institutions in the UK were changed. See, for example, Wood (2000). Effective August 23, 2003, the Republican Bush Administration in the United States adopted changes in the rules interpreting the provisions of the legislation that require overtime that, by one estimate, will reduce by 6.7 million the number of employees in the U.S. eligible for overtime (United States Department of Labor, 2004; Eisenbrey and Bernstein, 2003). 
On balance, it is believed that the Block-Roberts methodology for measuring labour standards across political jurisdiction is a potentially useful tool for measuring the effect of labour standards across jurisdictions that are comparable in terms of level of development and democratic institutions. Whether it can be adapted to measure labour standards in less developed countries, or in countries without strong democratic institutions, will be answered by further research.

The most common alternative to the Block-Roberts relativistic methodology is the methodology of using ILO data and information on convention ratification. While ILO data have the advantage of being generally universalist, they are fundamentally designed for internal ILO purposes - to analyze compliance with ILO conventions ratified. Thus they are constrained by the nature of the ILO system with its supervisory machinery and the associated dialogue (Liang, 2004).

Finally, it must be noted that this paper has not attempted to develop a general critique of the overall methodology that researchers have used to analyze the impact of labour standards on trade and trade-related phenomena. Rather, the purpose of this paper is to ask researchers to think clearly about the key variable in such a study - the measure of labour standards used. 


\section{References}

Becker, Elizabeth, 2004. “Amid a Trade Deal, A Debate Over Labor,” The New York Times, April 6, Section C, p. 1.

Block, Richard N., Peter Berg, and Karen Roberts, 2003. "Comparing and Quantifying Labour Standards in the United States and the European Union,” The International Journal of Comparative Labour Law and Industrial Relations, Vol. 19 (Winter), pp. 41-67.

Block, Richard N., JeongHyun Lee, and Eunjong Shin, 2002. "The Korean Industrial Relations System: From Post-Independence to Post-IMF,” in Korean Business Management: The Reality and the Vision, and Eunmi Chang, eds., Elizabeth, New Jersey and Seoul: Hollym, pp. 309-43.

Block, Richard N. and Karen Roberts, 2000, "A Comparison of Labour Standards in the United States and Canada,” Relations Industrielles/Industrial Relations, Vol. 55, No. 2, Spring, pp. 273-307.

Block, Richard N., Karen Roberts, and R. Oliver Clarke, 2003, Labor Standards in the United States and Canada, Kalamazoo, Michigan: W.E. Upjohn Institute for Employment Research.

Block, Richard N., Karen Roberts, Cynthia Ozeki, and Myron Roomkin, 2001, "Models of International Labor Standards,” Industrial Relations, Vol. 40 (April), pp. 258-92.

Böhning, W.R., 2003, “Gaps in Basic Workers' Rights: Measuring International Adherence To and Implementation of the Organization's Values With Public ILO Data,’ Working Paper, International Labour Office, May.

Busse, Matthias. 2001. "Do Labour Standards Affect Comparative Advantage? Evidence for Labour-intensive Goods,” Centre for International Economic Studies Discussion Paper No. 0142.

Cuyvers, Ludo and Daniel Van Den Bulcke, "The Quantification Of Respect For Selected Core Labor Standards : Towards A Social Development Index?,” paper presented at ILO Staff Seminar on Qualitative Indicators of Labour Standards and their Application, ILO, Geneva, Switzerland, 14-15 September 2004.

Dunlop, John T. 2002. "Project Labor Agreements," Harvard University Joint Center for Housing Studies Working Paper Series, W02-7.

Eisenbrey, Ross and Jared Bernstein, 2003, Eliminating the Right To Overtime Pay: Department of Labor Proposal Means Lower Pay, Longer Hours For Millions Of Workers," Economic Policy Institute Briefing Paper, June 26, at http://www.epinet.org/content.cfm/briefingpapers_flsa_jun03.

Elliott, Kimberly Ann, 2004, “Labor Standards, Development, and CAFTA,” Policy Brief PB04-2, Institute of International Economics, March.

Flanagan, Robert J., 2003. "Labor Standards and International Comparative Advantage," in International Labor Standards: Globalization, Trade, and Public Policy, Robert J. Flanagan and William B. Gould, IV, eds., Stanford, CA: Stanford University Press, pp. 15-59. 
Freedom House, undated, "Freedom in the World, 2003: Survey Methodology," at http://www.freedomhouse.org/research/freeworld/2003/methodology.htm.

Freedom House, undated-b, "Freedom in the World, 2004: Table of Independent Countries Comparative Measures of Freedom, at http://www.freedomhouse.org/research/freeworld/2004/table2004.pdf.

Galli, Rossana and David Kucera, 2004. "Labor Standards and Informal Employment in Latin America,” World Development, Vol. 20, forthcoming.

Heckman, James J. and Carmen Pages-Serra, 2000. "The Cost of Job Security Regulation: Evidence from Latin American Labor Markets,” Economia, Vol. 1, pp. 109-44.

Kucera, David, 2001. "Fundamental Rights at Work” as Determinants of Manufacturing Wages and FDI Inflows, International Labor Office, unpublished, 2001.

Kucera, David and Ritash Sarna, 2004. "International Trade and Freedom of Association and Collective Bargaining Rights: A Bilateral Gravity Model Approach," International Labor Office, January 2005.

Liang, Oliver, 2004, “Informational dimensions of the ILO's Committee of Experts,” paper presented at ILO Staff Seminar on Qualitative Indicators of Labour Standards and their Application, ILO, Geneva, Switzerland, 14-15 September 2004.

Lee, Yeon-ho, 1997. “The State, Society, and Big Business in South Korea,” London and New York: Routledge.

Mai, Jai S., 1997. "Core Labour Standards and Export Performance in Developing Countries,” The World Economy, Vol 20 (September), pp. 773-85.

Marleau, Veronique, 2003. "Globalization and the Problem of Compound Decentralization: Lessons from the Canadian Labour Relations Setting," paper presented at 'The Decentralization of Labour Policies and Collective Bargaining,' International Seminar in Commemoration of Marco Biagi, Modena, Italy, March 1920.

Maskus, Keith. 2003. "Trade and Competiveness Aspects of Environmental and Labor Standards in East Asia,” in Kathie Krumm and Homi Kharas (eds.) East Asia Integrates: A Trade Policy Agenda for Shared Growth, Washington, DC: The World Bank. pp. 115-34.

Organisation for Economic Co-operation and Development. 1996. Trade, Employment and Labour Standards: A Study of Core Workers’ Rights and International Trade. Paris: OECD.

Rodrik, Dani, 1996, in Robert Z. Lawrence, Dani Rodrik, and John Whalley, "Emerging Agenda for Global Trade,” Washington, DC: Overseas Development Council, pp. 35-79.

Social Accountability International, undated, "SA 8000: Overview of SA 8000," at http://www.cepaa.org/SA8000/SA8000.htm.

Springer, Beverly, 1994. "The European Union and Its Citizens: The Social Agenda," Wesport, Connecticut: Greenwood Press. 
Turner, Thomas, 2002, "Corporatism in Ireland: A Comparative Perspective," in Irish Employment Relations in the New Economy, D. D’Art and Thomas Turner, eds., Dublin, Blackhall Publishers.

United States Bureau of Labor Statistics, undated, National Compensation Survey: Employee Benefits Survey, at http://www.bls.gov/ncs/home.htm.

United States Department of Labor, 2004, “FairPay: DOL's FairPay Overtime Initiative,” Employment Standards Administration, Wage and Hour Division, August 23, at http://www.dol.gov/esa/regs/compliance/whd/fairpay/main.htm.

United States General Accounting Office, 2002, "Collective Bargaining Rights: Information on the Number of Workers With and Without Bargaining Rights," Report to Congressional Requesters, U.S. Senate, GAO 02-835, September, at http://www.gao.gov/new.items/d02835.pdf.

Wood, Stephen, 2000. "From Voluntarism to Partnership: A Third Way Overview of the Public Policy Debate in British Industrial Relations," in Legal Regulation of the Employment Relationship, Hugh Collins, Paul Davies, and Roger Rideout, eds., London: Kluwer Law International, pp. 111-35. 


\section{Tables}

Table 1: MINIMUM WAGE INDEX: PROVISIONS, WEIGHTS, SUBINDEX VALUES

\begin{tabular}{lllll}
\hline PROVISIONILANGUAGE & PROVISION & SUBINDEX & PROVISION & SUBINDEX \\
& WEIGHT & VALUE & WEIGHT & VALUE \\
& U.S.- Canada & U.S.- Canada & U.S.-E.U. & U.S.-E.U. \\
\hline
\end{tabular}

Minimum Wage Level (as of April 1, 1997)

.92

.95

GT or EQ U.S.\$5.00IGT or EQ C\$6.90

10.00

U.S.\$4.75 - U.S.\$4.99IC\$6.55 - C\$6.89

8.57

U.S.\$4.50 - U.S.\$4.74IC\$6.21 - C\$6.54

7.14

U.S. $\$ 4.25$ - U.S. $\$ 4.491 C \$ 5.86$ - C $\$ 6.20$

5.51

U.S.\$4.00 - U.S.\$4.24IC\$5.52 - C\$5.85

4.28

U.S.\$3.75 - U.S.\$3.99IC\$5.17 - C\$5.51

2.85

U.S.\$3.50 - U.S.\$3.74IC\$4.83 - C\$5.16.

1.42

Subminimum Wage

.04

.05

Coded as 10 if province has no subminimum or if subminimum wage would bring wage paid below state minimum,where state minimumis higher than federal minimum, zero otherwise

Fines Imprisonment

Coded as 10 if fines or imprisonment a possible sanction on violator, zero otherwise 
Table 2: Overtime/Working time index: Provisions, weights, sub index values United States - Canada and United States - European Union comparision.

\begin{tabular}{lllll}
\hline & \multicolumn{1}{c}{ II } & \multicolumn{1}{c}{ III } & \multicolumn{1}{c}{ IV } & \multicolumn{1}{c}{ V } \\
\cline { 2 - 5 } & PROVISION & SUBINDEX & PROVISION & SUBINDEX \\
PROVISION/LANGUAGE & WEIGHT & VALUE & WEIGHT & VALUE \\
\hline
\end{tabular}

Overtime

.95

.35

$1.5 \mathrm{x}$ reg rate after $40 \mathrm{hrs}$. per week 10

$2 \times$ reg rate after 48 hours per week

$1.5 \mathrm{x}$ reg rate after 44 hours per week

$1.5 \mathrm{x}$ reg rate after 48 hours per week

$1.5 \times$ min wage after 40 hours per week

$1.5 \times$ min wage after 44 hours per week

Employee Right to Refuse Overtime

Specified Number of Hours of Rest in 24 Hours

Rest/Meal Required During Day after 5/6 Hrs. Work 
Table 3: Paid time off index: Provisions, weights, sub index values.

\begin{tabular}{lllll}
\hline & \multicolumn{1}{c}{ II } & \multicolumn{1}{c}{ III } & & IV \\
\cline { 2 - 5 } Provision/Language & PROVISION & SUBINDEX & PROVISION & SUBINDEX \\
& WEIGHT & VALUE & WEIGHT & VALUE \\
& U.S.- Canada & U.S.- Canada & U.S.-E.U. & U.S.-E.U. \\
\hline
\end{tabular}

Holidays

165

$13+$ days of holiday

10

$12-12.9$ days

11 - 11.9 days

9 - 9.9 days

8 - 8.9 days

$7-7.9$ days

.3

6 - 6.9 days

.2

5 - 5.9 days

.1

Less Than 5 days

0

Pay for Holidays not Worked or OT for Holidays Worked .335

Coded 10 if the jurisdiction requires that employees be paid for holidays not worked or be granted overtime for holidays worked, zero otherwise

Vacation LengthIPay Coding

.45

3 Weeks Vacation, $6 \%$ of Pay Reg pay 10

2 Weeks Vacation, 6\% of Pay

2 Weeks Vacation, 4\% of Pay or Reg Pay

2 Weeks Vacation, $6 \%$ of Pay

No Vacation, no Pay

When Entitled Coding

.05

After 10 mos with employer

After 12 mos. With employer

After more than 12 mos. With employer

3.33

No provision

0

Holidays Specified

Pay for Holidays not Worked or Overtime for Holidays 
Table 4: Unemployment/employment insurance: Provisions, weights, sub index values.

\begin{tabular}{|c|c|c|}
\hline ProvisionlLanguage & $\begin{array}{l}\text { PROVISION } \\
\text { WEIGHT } \\
\text { U.S.- Canada }\end{array}$ & $\begin{array}{l}\text { SUBINDEX } \\
\text { VALUE } \\
\text { U.S.- Canada }\end{array}$ \\
\hline Taxable Wage Base, U. S. Dollars & .1 & \\
\hline GT or EQ U.S. $\$ 30,000 I C \$ 41,100$ & & 10 \\
\hline U.S. $\$ 25,000$ - U.S. $\$ 29,999 \mid C \$ 34,250$-C $\$ 41,099$ & & 8.3 \\
\hline U.S. $\$ 20,000$ - U.S. $\$ 24,999 \mid C \$ 27400$ - C $\$ 34,249$ & & 6.7 \\
\hline U.S.\$15,000 - U.S.\$19,999IC\$20,500 - C $\$ 27,399$ & & 5.0 \\
\hline U.S.\$10,000 - U.S.\$14,999IC\$13,700 - \$20,499 & & 3.3 \\
\hline U.S. $\$ 5,000$ - U.S. $\$ 9,9999 \mid C \$ 6850$ - C $\$ 13,699$ & & 1.7 \\
\hline Employee Tax Rate & .3 & \\
\hline No Employee Tax & & 10 \\
\hline GT 0 but LT 1\% & & 8.3 \\
\hline $1 \%-2 \%$ & & 6.7 \\
\hline $2 \%-3 \%$ & & 5.0 \\
\hline $3 \%-4 \%$ & & 3.3 \\
\hline $4 \%-5 \%$ & & 1.7 \\
\hline Coding, Avg. Weekly Benefit as a Percentage of Avg. Weekly Wages & .35 & \\
\hline $45 \%-49 \%$ & & 8.3 \\
\hline $40 \% 44 \%$ & & 6.7 \\
\hline $35 \%-39 \%$ & & 5.0 \\
\hline $30 \%-34 \%$ & & 3.3 \\
\hline LT 30\% & & 1.7 \\
\hline Coding, Maximum Total Benefit/Extended Benefits & .25 & \\
\hline 45 weeks & & 10 \\
\hline 43 weeks & & 7.5 \\
\hline 39 weeks & & 5.0 \\
\hline 26 weeks & & 2.5 \\
\hline
\end{tabular}


Table 5: Workers' compensation (employment injury): Provisions, weights, sub index values.

\begin{tabular}{|c|c|c|}
\hline Provision & $\begin{array}{l}\text { PROVISION } \\
\text { WEIGHT } \\
\text { U.S.- Canada }\end{array}$ & $\begin{array}{c}\text { SUBINDEX } \\
\text { VALUE } \\
\text { U.S.- Canada }\end{array}$ \\
\hline \multicolumn{3}{|l|}{ Compulsory Coverage } \\
\hline Compulsory Coverage for Private Employment & .024 & \\
\hline No Waivers Permitted & .024 & \\
\hline No Exemption Based on Firm Size & .047 & \\
\hline Farm workers Covered & .047 & \\
\hline Casual and Household Workers Covered & .047 & \\
\hline Mandatory Government Worker Coverage & .047 & \\
\hline No Exemptions based on Employee Class & .047 & \\
\hline Employee Choice over Where to File & .000 & \\
\hline Coverage for All work-Related Diseases & .047 & \\
\hline TTD Benefits $=662 / 3 \%$ Wages & .047 & \\
\hline Maximum TTD Benefit at least 100\% SAWW & .047 & \\
\hline Retain Prevailing PT Definition & .047 & \\
\hline PT Benefits = 66 2/3\% Wages (s.t. maximum) & .047 & \\
\hline Maximum PT Benefit at least 100\% SAWW & .047 & \\
\hline Benefit Duration = Disability Duration & .047 & \\
\hline Death Benefits = 66 2/3\% Wages & .047 & \\
\hline Maximum Death Benefit at least 100\% SAWW & .047 & \\
\hline Continuation of Benefits to Widow(er) & & .024 \\
\hline Lump Sum to Widow(er) on Remarriage & & .008 \\
\hline Cont. of Benefits to Dep. Children until 18 & & .008 \\
\hline Continuation of Benefits to Dependent Benefits until 25 if Student & & .008 \\
\hline No Statutory \$ Limit on Medical or Rehab Svs. & .047 & $0-10$ \\
\hline No Time Limit on Right to Medical or Rehab Svs. & .047 & $0-10$ \\
\hline Right of Appeal & & $0-10$ \\
\hline Internal First Level Agency & .05 & $0-10$ \\
\hline Internal Appeal Process & .05 & $0-10$ \\
\hline Levels of Appeal beyond first & .05 & $0-10$ \\
\hline
\end{tabular}


Table 6: Collective bargaining: Provisions: weights, sub index values.

\begin{tabular}{lcccc}
\hline & \multicolumn{1}{c}{ II } & III & IV & V \\
\cline { 2 - 5 } Provision/Language & $\begin{array}{l}\text { PROVISION } \\
\text { WEIGHT }\end{array}$ & $\begin{array}{l}\text { SUBINDEX } \\
\text { VALUE }\end{array}$ & $\begin{array}{l}\text { PROVISION } \\
\text { WEIGHT }\end{array}$ & $\begin{array}{c}\text { SUBINDEX } \\
\text { VALUE } \\
\text { U.S.-E.U. }\end{array}$ \\
\hline Statutory Protection for Collective Bargaining & .15 & $0-10$ & .67 & $0-10$ \\
Election Not Req. if Evidence that Majty. Support Union & .2 & $0-10$ & \\
Unlimited Subjects of Bargaining & .1 & $0-10$ & \\
Conciliation during Negs Compulsory at Request of Gov=t & .2 & $0-10$ & \\
or one party & & & \\
Striker Permanent Replacements Prohibited & .1 & $0-10$ & \\
First Agreement Arbitration Available & .1 & $0-10$ & \\
Limits on Rights of Loser to Appeal & .15 & $0-10$ & \\
Formal Union Involvement in Policymaking & & & \\
\hline
\end{tabular}


Table 7: Equal employment opportunityl employment equity: Provisions, weights, sub index values.

\begin{tabular}{|c|c|c|c|c|}
\hline & .053 & .053 & .053 & .053 \\
\hline Provision/Language & $\begin{array}{l}\text { PROVISION } \\
\text { WEIGHT } \\
\text { U.S.- Canada }\end{array}$ & $\begin{array}{l}\text { SUBINDEX } \\
\text { VALUE } \\
\text { U.S.- Canada }\end{array}$ & $\begin{array}{l}\text { PROVISION } \\
\text { WEIGHT } \\
\text { U.S.-E.U. }\end{array}$ & $\begin{array}{l}\text { SUBINDEX } \\
\text { VALUE } \\
\text { U.S.-E.U. }\end{array}$ \\
\hline Race, Visual Minorities, Aboriginal Peoples & .15 & & .05 & $0-10$ \\
\hline Gender & .15 & & .1 & $0-10$ \\
\hline National/Origin/Ancestry & .1 & & .05 & $0-10$ \\
\hline Religion & .1 & & .1 & $0-10$ \\
\hline Age & .1 & & .05 & $0-10$ \\
\hline No Exceptions & & 10 & & \\
\hline Retirement Plan Exceptions & & 5 & & \\
\hline Age Not Covered & & 0 & & \\
\hline Sexual Preference/Orientation & .05 & & .05 & $0-10$ \\
\hline Disability & .1 & & .11 & $0-10$ \\
\hline Political Beliefs/Org Memberships & .05 & & & \\
\hline $\begin{array}{l}\text { Family Leave due to Prgnancy, Illness of Family } \\
\text { Member, or SerioU.S. Health Problem, 12-17 weeks } \\
\text { unpaid }\end{array}$ & .05 & & & \\
\hline Sexual Harassment Covered & .03 & & .03 & $0-10$ \\
\hline Equal Pay Covered & .03 & & .03 & $0-10$ \\
\hline Reasonable Accomm. for Disabled Employees & .04 & & .04 & $0-10$ \\
\hline Limits on rights of Appeal & .05 & & & \\
\hline
\end{tabular}


Table 8: Unjust discharge: Provisions, weights, sub index values

\begin{tabular}{lll}
\hline Provision/Language & $\begin{array}{l}\text { Provision } \\
\text { Weight }\end{array}$ & $\begin{array}{l}\text { Subindex } \\
\text { Value }\end{array}$ \\
\hline
\end{tabular}

Discharge Prohibited if Employee has Implicit Contract .05

Definitive State Ruling in favor of exception 10

No court decision

Definitive State Ruling against exception

\section{Handbook Exception}

.05

Definitive State Ruling in favor of exception 10

No court decision

Definitive State Ruling against exception

\section{Public Policy Exception}

1

Definitive State Ruling in favor of exception

No court decision

Definitive State Ruling against exception

\section{Covenant of Good Faith Exception}

Definitive State Ruling in favor of exception

No court decision

Definitive State Ruling against exception to@Good Cause@ 
Table 9: Occupational safety and health: Provisions, weights, sub index values

\begin{tabular}{lllll}
\hline & \multicolumn{1}{c}{ II } & \multicolumn{1}{c}{ III } & \multicolumn{1}{c}{ IV } & V \\
\cline { 2 - 5 } Provision/Language & PROVISION & SUBINDEX & PROVISION & SUBINDEX \\
& WEIGHT & VALUE & WEIGHT & VALUE \\
& U.S.- Canada & U.S.- Canada & U.S.-E.U. & U.S.-E.U. \\
\hline
\end{tabular}

Subject to General Duty Clause

Inspection Warrant can be demanded prior to inspector entry

Maximum penalty for a willful violation of statue

$3 \mathrm{GT}$ or $=\$ 100,000$

$\$ 80,000-\$ 99,999$

$\$ 60,000-\$ 79,000$

$\$ 40,000$ - $\$ 59,999$

$\$ 20,000$ - $\$ 39,999$

$\$ 1,000$ - $\$ 19,999$

no penalty

All dollar amounts are domestic.

Maximum penalty for a serious violation of statue

See coding on "Maximum Penalty for a serious violation of statute."

Max. penalty for willful repeat violation

For coding, see column entittle "Maximum Penalty for a Willful Violation of Statute."

Repeat viol. penalties may be increased by factor of 10

Penalty for 1st offense, willful violaiton causing a death

For Coding see Column entitled AMaximum Penalty for a Willful Violation of Statute@

Penalty for 2nd offense, willful viol. causing death

For Coding see Column entitled AMaximum Penalty for a Willful Violation of Statute@

Daily penalty for until hazard corrected

0.53

GT or $=\$ 10,000$

10

$\$ 8,000$ - $\$ 9999$

8.3

$\$ 6,000$ - $\$ 7,999$

6.7

$\$ 4,000$ - $\$ 6,999$

5.0

$\$ 2,000-\$ 3,999$

3.3

$\$ 1$ to $\$ 1,999$

no fine

All fines in domestic dollars. 
Table 9 continued

\begin{tabular}{|c|c|c|c|c|}
\hline & II & III & IV & V \\
\hline Provision/Language & $\begin{array}{l}\text { PROVISION } \\
\text { WEIGHT } \\
\text { U.S.- Canada }\end{array}$ & $\begin{array}{l}\text { SUBINDEX } \\
\text { VALUE } \\
\text { U.S.- Canada }\end{array}$ & $\begin{array}{l}\text { PROVISION } \\
\text { WEIGHT } \\
\text { U.S.-E.U. }\end{array}$ & $\begin{array}{l}\text { SUBINDEX } \\
\text { VALUE } \\
\text { U.S.-E.U. }\end{array}$ \\
\hline Red. in penalties for firms with up to 250 employees & .02 & & & \\
\hline Reduction for written health and safety program & .02 & & & \\
\hline Penalty Red. if no violations during a specified time & .02 & & & \\
\hline Recordkeeping exmptn. for small firms/ specified inds. & .02 & & & \\
\hline State may set stricter standards than federal govt. & .053 & & & \\
\hline $\begin{array}{l}\text { Safety Committee or Representative/Worker Consultation } \\
\text { Required }\end{array}$ & .053 & & .20 & $0-10$ \\
\hline Maximum imprisonment possible & .053 & & & \\
\hline 24 months & & 10 & & \\
\hline 12 months & & 8 & & \\
\hline 6 months & & 6 & & \\
\hline 3 months & & 4 & & \\
\hline 1 month & & 2 & & \\
\hline Max. penalty for contravening inspector & 0.53 & & & \\
\hline$=$ or $\mathrm{GT} \$ 100,000$ & & 10 & & \\
\hline$\$ 80,000$ - $\$ 99,999$ & & 8.3 & & \\
\hline$\$ 60,000-\$ 79,999$ & & 6.7 & & \\
\hline$\$ 40,000-\$ 59,999$ & & 5.0 & & \\
\hline$\$ 20,000-\$ 39,999$ & & 3.3 & & \\
\hline$\$ 1,000-\$ 19,999$ & & 1.7 & & \\
\hline no penalty & & 0 & & \\
\hline Maximum penalty for any contravention by anyone & .053 & & & \\
\hline \multicolumn{5}{|l|}{$\begin{array}{l}\text { For coding, see column entitled "Daily Penalty Assessed for } \\
\text { Failing to Abate a Hazard Until Corrected." }\end{array}$} \\
\hline Maximum Penalty for minor offenses & .053 & & & \\
\hline \multicolumn{5}{|l|}{$\begin{array}{l}\text { For coding, see column entitled "Daily Penalty Assessed for } \\
\text { Failing to Abate a Hazard Until Corrected." }\end{array}$} \\
\hline Additional Fines Possible & .053 & & & \\
\hline $\begin{array}{l}\text { Daily penalty assessed for failing to correct a second } \\
\text { hazard }\end{array}$ & .053 & & & \\
\hline \multicolumn{5}{|l|}{$\begin{array}{l}\text { For coding, see column entitled "Daily Penalty Assessed for } \\
\text { Failing to Abate A Hazard Until Corrected." }\end{array}$} \\
\hline Limits on Appeal of Agency Decisions & .052 & & & \\
\hline Standards for Chemicals/Contaminants & & & .15 & $0-10$ \\
\hline Worker Must Be Informed of Job Risks & & & .20 & $0-10$ \\
\hline Worker Training Requirement & & & .20 & $0-10$ \\
\hline Working Environment (Psychological Factors) & & & .05 & $0-10$ \\
\hline
\end{tabular}


Table 10: Advance notice of plant closings/ large scale layoffs: Provisions, weights, sub index values

\begin{tabular}{|c|c|c|c|c|}
\hline & II & III & IV & v \\
\hline Provision/Language & $\begin{array}{l}\text { PROVISION } \\
\text { WEIGHT } \\
\text { U.S.- Canada }\end{array}$ & $\begin{array}{l}\text { SUBINDEX } \\
\text { VALUE } \\
\text { U.S.- Canada }\end{array}$ & $\begin{array}{l}\text { PROVISION } \\
\text { WEIGHT } \\
\text { U.S.-E.U. }\end{array}$ & $\begin{array}{l}\text { SUBINDEX } \\
\text { VALUE } \\
\text { U.S.-E.U. }\end{array}$ \\
\hline \# of EES & .2 & & .35 & $0-10$ \\
\hline $10+$ ees & & 10 & & \\
\hline $25+$ ees & & 6.7 & & \\
\hline $50+$ ees & & 3.3 & & \\
\hline NP & & 0 & & \\
\hline Max. Time Period in Which Layoffs Must Occur & .04 & & & \\
\hline No Max time & & 10 & & \\
\hline 4-5 weeks & & 6.7 & & \\
\hline 8 weeks & & 3.3 & & \\
\hline NP & & 0 & & \\
\hline Advanced Notice Required & .2 & & .25 & $0-10$ \\
\hline$>1=16$ weeks $=10$ & & 10 & & \\
\hline 12 to $<16$ weeks $=7.5$ & & 7.5 & & \\
\hline 8 to $<12$ weeks $=5$ & & 5 & & \\
\hline 4 to $<8$ weeks $=2.5$ & & 2.5 & & \\
\hline no notice required & & 0 & & \\
\hline Notice to Minister of Labour or Government & .01 & & .05 & $0-10$ \\
\hline Notice to affected employees & .2 & & .2 & $0-10$ \\
\hline Notice to Union & .1 & & .15 & $0-10$ \\
\hline Severance Pay & .2 & & & \\
\hline Limits on Appeal of Agency Decisions & .05 & & & \\
\hline
\end{tabular}


Table 11: Employees' rights to information and consultation: Provisions, weights and sub index values

\begin{tabular}{|c|c|c|}
\hline & II & III \\
\hline Provision/Language & $\begin{array}{l}\text { PROVISION } \\
\text { WEIGHT } \\
\text { U.S.-E.U. }\end{array}$ & $\begin{array}{l}\text { SUBINDEX } \\
\text { VALUE } \\
\text { U.S.-E.U. }\end{array}$ \\
\hline Right to Information/Consultation & 1 & $0-10$ \\
\hline
\end{tabular}

Table 12: Parental and family leave: Provisions, weights, sub index values

\begin{tabular}{|c|c|c|}
\hline & ॥ & III \\
\hline Provision/Language & $\begin{array}{l}\text { PROVISION } \\
\text { WEIGHT } \\
\text { U.S.-E.U. }\end{array}$ & $\begin{array}{l}\text { SUBINDEX } \\
\text { VALUE } \\
\text { U.S.-E.U. }\end{array}$ \\
\hline Maternity Leave & .25 & $0-10$ \\
\hline Family Leave & .5 & $0-10$ \\
\hline Parental Leave due to Family Illness (14 weeks per year) & .25 & $0-10$ \\
\hline
\end{tabular}

Table 13: Transfer of undertaking/ownership: Provisions, weights, sub index values

\begin{tabular}{lcc}
\hline & \multicolumn{1}{c}{ III } \\
\cline { 2 - 3 } Provision/Language & $\begin{array}{l}\text { PROVISION } \\
\text { WEIGHT }\end{array}$ & $\begin{array}{l}\text { SUBINDEX } \\
\text { VALUE }\end{array}$ \\
\hline Contracts of Employment & U.S.-E.U. & U.S.-E.U. \\
Collective Bargaining Obligations & .15 & $0-10$ \\
Protection from Dismissal Due Solely to Transfer & .15 & $0-10$ \\
Information Provision to Employees Representatives & .4 & $0-10$ \\
Consultation with Employees in Matters in Relation to Employees & .15 & $0-10$ \\
\hline
\end{tabular}




\section{Policy Integration Department Working Papers}

No. 1 ILO activities on the social dimension of globalization: Synthesis report

No. 2 Measuring decent work with statistical indicators

Richard Anker, Igor Chernyshev, Philippe Egger, Farhad Mehran and Joseph Ritter

No. 3 Globalization and decent work: Options for Panama Philippe Egger

No. 4 Globalización y trabajo decente: Opciones para Panamá Philippe Egger

No. 5 Indicators of social dialogue: Concepts and measurements Lane Kenworthy and Bernhard Kittel

No. 6 Assessing the impact of the attacks of 11 September 2001 on women's employment in the United States

Gertrude Schaffner Goldberg and Helen Lachs Ginsburg

No. 7 Decent work and the informal economy in Central America Juan Diego Trejos Solórzano and Miguel Del Cid

No. 8 Poverty initiatives in the ILO: A review of past and present approaches Pat Holden and Dagmar Walter

No. 9 Whither the International Standard Classification of Occupations (ISCO-88)? Debbie Budlender

No. 10 Improving occupational classifications as tools for describing labour markets: A summary of recent national experiences

Debbie Budlender

No. 11 Recent developments in China's labour economy Thomas G. Rawski

No. 12 The Impact of economic liberalization on employment and wages in India Sonia Bhalotra

No. 13 The impact of trade liberalization upon inequality in developing countries Donald J. Robbins

No. 14 The impact of liberalization and globalization on income inequality in developing and transitional economies Giovanni Andrea Cornia

No. 15 The impact of technology transfer on employment and income distribution in developing countries: A survey of theoretical models and empirical studies Mariacristina Piva 


\section{Policy Integration Department Working Papers \\ Prepared by the World Commission on the \\ Social Dimension of Globalization}

No. 16 International finance: Meeting the needs of people in developing countries José Guilherme Almeida dos Reis

No. 17 The gender dimensions of globalization of production Stephanie Barrientos, Naila Kabeer and Naomi Hossain

No. 18 Social exclusion in the context of globalization - Jan Breman

No. 19 Gender and globalization: A macroeconomic perspective Çağatay Nilüfer and Ertük Korkurt

No. 20 Globalization, social exclusion, and work: with special reference to informal employment and gender - Marilyn Carr and Martha Chen

No. 21 Resources for social development - Antony Clunies Ross

No. 22 Does the new international trade regime leave room for industrialization policies in the middle-income countries? - Alisa DiCaprio and Alice Amsden

No. 23 Social dimension of globalization in Latin America: Lessons from Bolivia and Chile, Ivaro García Hurtado

No. 24 The social dimension of globalization: a review of the literature Bernhard Gunter and Rolph van der Hoeven

No. 25 The social dimension of global production systems: A review of the issues, Susan Hayter

No. 26 Reforming global economic and social governance:

a critical review of recent programmatic thinking - Jeremy Heimans

No. 27 Corporate social responsibility: an issues paper - Michael Hopkins

No. 28 Upgrading in global value chains - John Humphrey

No. 29 Implications of globalization and economic restructuring for skills development in Sub-Saharan Africa - Richard K. Johanson

No. 30 The outcome and impact of the main international commissions on development issues Frédéric Lapeyre

No. 31 Globalization and structural adjustment as a development tool - Frédéric Lapeyre

No. 32 Globalization and perceptions of social inequality - Malte Luebker

No. 33 The changing structure of international trade linked to global production systems: what are the policy implications? - William Milberg

No. 34 Corporate social responsibility: an overview of principles and practice,Jill Murray

No. 35 Inclusive development strategy in an era of globalization - Ignacy Sachs

No. 36 Social consequences of the globalization of the media and communication sector: some strategic considerations - Seán Ó. Siochrú

No. 37 Globalization, history and international migration: a view from Latin America Andrés Solimano

No. 38 Towards a different kind of globalization, or how the anti-globalists view the world Gijsbert van Liemt 


\section{Policy Integration Department Working Papers}

No. 39 How do trade union rights affect trade competitiveness? David Kucera and Ritash Sarna

No. 40 Statistics on the employment situation of people with disabilities:

A compendium of national methodologies

ILO Bureau of Statistics in collaboration with the In Focus Programme on Skills, Knowledge and Employability

No. 41 Employment in the informal economy in the Republic of Moldova ILO Bureau of Statistics in collaboration with the Department for Statistics and Sociology of the Republic of Moldova

No. 42 Decent work in a least developed country: A critical assessment of the Ethiopia PRSP Graeme J. Buckley

No. 43 Unemployment and Labour Market Institutions:

The Failure of the Empirical Case for Deregulation

Dean Baker, Andrew Glyn, David Howell and John Schmitt

No. 44 Women's access to occupations with authority, influence and decision-making power: Women as legislators, senior officials and managers around the world Richard Anker.

No. 45 The world of work in the context of economic integration and trade liberalization Daniel Martínez

No. 46 Poverty reduction in Pakistan: The strategic impact of macro and employment policies Moazam Mahmood

No. 47 Trends in Work Stoppages: A Global Perspective L. J. Perry and Patrick J. Wilson

No. 48 Generating decent work for poverty reduction in Cambodia: The voice of workers, employers and the Government Moazam Mahmood

No. 49 The Social Dimension of Regional Integration in ECOWAS René Robert

No. 50 Measuring trade union rights: A country-level indicator constructed from coding violations recorded in textual sources David Kucera

No. 51 Patterns of job quality attributes in European Union Joseph A. Ritter

No. 52 Child Labour, Education and Export Performance

David Kucera and Ritash Sarna 
No. 53 Measuring the informal economy: From employment in the informal sector to informal employment

Ralf Hussmanns

No. 54 Indicators of labour standards: an overview and comparison

Richard N. Block 